\title{
The activity of selected herbicides with addition of soil adjuvants in winter wheat
}

\section{Aktywność wybranych herbicydów z dodatkiem adiuwantów doglebowych w pszenicy ozimej}

\author{
Roman Kierzek $^{1 *}$, Radosław Grychowski ${ }^{2}$, Henryk Ratajkiewicz ${ }^{3}$, Krystyna Miklaszewska ${ }^{1}$
}

\begin{abstract}
Summary
The aim of this study was to evaluate activity of herbicides Komplet 560 SC (flufenacet and diflufenican) and Expert Met 56 WG (flufenacet and metribuzin) with addition of soil adjuvants in winter wheat. The herbicides were used in a tank-mixture with the adjuvants Grounded $(0.4 \mathrm{l} / \mathrm{ha})$ and $\mathrm{OSOL}(0.25 \mathrm{l} / \mathrm{ha})$. The herbicides were applied at the recommended doses: Komplet $560 \mathrm{SC}$ $-0.5 \mathrm{l} / \mathrm{ha}$, Expert Met 56 WG $-0.35 \mathrm{~kg} / \mathrm{ha}$. The experiments were conducted over two growing seasons (2015/2016 and 2016/2017) at the Experimental Station of the Institute of Plant Protection in Winna Góra in a randomized block design with four replications. The tested herbicides were applied at a growth stage of first leaf unfolded to two leaves unfolded (BBCH 11-12). The most common species of weeds were: Viola arvensis, Matricaria inodora, Polygonum convolvulus, Consolida regalis, Papaver rhoeas and Apera spica-venti. The use of tested adjuvants with soil herbicides at the full recommended doses had insignificant effect on weed control efficacy in winter wheat in autumn. The yield of winter wheat depended on weather condition, weed infestation and weed control efficacy. No phytotoxic effects of applied herbicides (separately and jointly with adjuvants) on winter wheat were observed.
\end{abstract}

Key words: winter wheat; weeds; herbicides; adjuvant

\section{Streszczenie}

Celem badań była ocena aktywności herbicydów Komplet 560 SC (flufenacet i diflufenikan) i Expert Met 56 WG (flufenacet i metrybuzyna) z dodatkiem adiuwantów doglebowych aplikowanych w pszenicy ozimej. Herbicydy stosowano wraz z adiuwantami Grounded (0,4 l/ha) i OSOL (0,25 l/ha). Herbicydy zastosowano w pełnych, zalecanych dawkach: Komplet 560 SC - 0,5 I/ha, Expert Met 56 WG - 0,35 kg/ha. Doświadczenia prowadzono przez dwa sezony wegetacyjne (2015/2016 i 2016/2017) na terenie Polowej Stacji Doświadczalnej Instytutu Ochrony Roślin - Państwowego Instytutu Badawczego w Winnej Górze w układzie bloków losowanych, w czterech powtórzeniach. Badane herbicydy aplikowano w fazie od pierwszego do drugiego liścia pszenicy ozimej (BBCH 11-12) Najczęściej występującymi gatunkami chwastów były: Viola arvensis, Matricaria inodora, Polygonum convolvulus, Consolida regalis, Papaver rhoeas oraz Apera spica-venti. Dodatek testowanych adiuwantów do herbicydów o działaniu głównie doglebowym stosowanych w pełnych dawkach w okresie jesiennym w pszenicy ozimej miał nieznaczny wpływ na skuteczność chwastobójcza. Plonowanie pszenicy ozimej było uzależnione od przebiegu warunków pogodowych, zachwaszczenia i skuteczności działania herbicydów. Badane herbicydy oraz ich mieszaniny z adiuwantami były selektywne dla roślin pszenicy ozimej.

Słowa kluczowe: pszenica ozima; chwasty; herbicydy; adiuwant

\footnotetext{
${ }^{1}$ Instytut Ochrony Roślin - Państwowy Instytut Badawczy

Władysława Węgorka 20, 60-318 Poznań

${ }^{2}$ Państwowa Inspekcja Ochrony Roślin i Nasiennictwa, Oddział Września

Sikorskiego 34, 62-300 Września

${ }^{3}$ Uniwersytet Przyrodniczy w Poznaniu, Katedra Entomologii i Ochrony Środowiska

Dąbrowskiego 159, 60-594 Poznań

*corresponding author: r.kierzek@iorpib.poznan.pl
} 


\section{Wstęp / Introduction}

Adiuwanty są zalecane i aplikowane przede wszystkim podczas zabiegów nalistnych (powschodowych) (Adamczewski i Matysiak 2005). Stosowane są z bardzo dobrymi rezultatami $\mathrm{z}$ herbicydami w obniżonych dawkach (Krogh i wsp. 2003; Foster i wsp. 2006). Wyniki badań wskazują, że stosowanie adiuwantów $\mathrm{z}$ herbicydami w zabiegach doglebowych (przedwschodowych) jest uzasadnione (Bayer i Foy 1982; Swarcewicz i wsp. 1998; Kucharski i Sadowski 2006). Użycie odpowiedniego adiuwanta może wydłużać działanie herbicydu w glebie (McMullan i wsp. 1998; Kucharski 2004). Działanie takiego adiuwanta polega między innymi na utrzymaniu pestycydu przy powierzchni gleby (Foy 1992; Jain i Singh 1992). Taką rolę mogą pełnić adiuwanty olejowe. Potwierdziły to badania Swarcewicza i wsp. (1998), w których wykazali oni zmniejszenie odparowywania trifluraliny oraz jej rozpraszania w glebie. Kucharski (2004) oraz Kucharski i Sadowski (2009) odnotowali natomiast, że adiuwant olejowy ograniczał stopień rozkładu fenmedifamu w glebie. Oddziaływanie surfaktantów nie jest jednoznaczne, ponieważ może być uzależnione w znacznie większym stopniu od stężenia, a ponadto wilgotności gleby oraz właściwości fizyczno-chemicznych substancji czynnej (Foy 1992). Notowano jednak zwiększenie poziomu pozostałości substancji czynnej (Kucharski i wsp. 2011, 2012). Należy pamiętać o tym, że surfaktanty bywają używane do zmniejszenia hydrofobowości gleby podczas nawadniania (Zontek i Kostka 2012).

Celem przeprowadzonych doświadczeń była ocena skuteczności działania herbicydów Komplet 560 SC i Expert Met 56 WG z dodatkiem adiuwantów doglebowych Grounded i OSOL w uprawie pszenicy ozimej.

\section{Materiały i metody / Materials and methods}

W trakcie dwóch sezonów wegetacyjnych 2015/2016 oraz 2016/2017 przeprowadzono doświadczenia polowe w uprawie pszenicy ozimej. Założono je na terenie Polowej Stacji Doświadczalnej Instytutu Ochrony Roślin - Państwowego Instytutu Badawczego w Winnej Górze leżącej w województwie wielkopolskim. Doświadczenia zaplanowano w układzie bloków losowanych, w czterech powtórzeniach z poletkami o powierzchni 16,5 $\mathrm{m}^{2}(11 \mathrm{~m} \times 1,5 \mathrm{~m})$. Pszenicę ozimą Arkadia (jakościowa odmiana chlebowa) uprawiano na glinie piaszczystej, wytworzonej z piasków gliniastych lekkich znajdującej się w klasie bonitacyjnej IIIb.

Herbicydy Komplet 560 EC w dawce 0,5 1/ha oraz Expert Met 56 WG w dawce 0,35 kg/ha stosowano pojedynczo oraz $\mathrm{w}$ mieszaninie $\mathrm{z}$ adiuwantem Grounded (rafinowany olej parafinowy w mieszaninie $\mathrm{z}$ etoksylowanym alkoholem oraz kwasami thuszczowymi - $732 \mathrm{~g} / \mathrm{l}$ ) w dawce 0,4 l/ha i OSOL (alkohol heksahydroksylowy $50 \%$ i koformulanty - 50\%) w dawce 0,25 l/ha. Oba herbicydy zawierają po dwie substancje czynne. W przypadku środka Komplet $560 \mathrm{SC}$ są to: flufenacet $(280 \mathrm{~g} / \mathrm{l})$ oraz diflufenikan (280 g/l), natomiast Expert Met 56 WG zawiera: flufenacet $(420 \mathrm{~g} / \mathrm{l})$ i metrybuzynę $(120 \mathrm{~g} / \mathrm{l})$. W obu herbicydach substancje czynne wzajemnie się uzupełniają.
Diflufenikan pobierany jest głównie przez korzenie kiełkujących chwastów, jak również przez liście. Flufenacet wnika przez korzenie i hipokotyl, zaś metrybuzyna głównie przez system korzeniowy, a w znacznie mniejszym stopniu przez liście. Wszystkie substancje pozostają aktywne w glebie przez wiele tygodni, co zabezpiecza przed kiełkowaniem kolejnych chwastów w późniejszym okresie. $\mathrm{W}$ doświadczeniach preparaty aplikowano $\mathrm{w}$ fazie $\mathrm{BBCH}$ 11-12, tzn. w fazie od pierwszego do drugiego liścia pszenicy ozimej. Zabiegi wykonano opryskiwaczem poletkowym przy użyciu rozpylaczy szczelinowych Tee-Jet AIXR 11003 i ciśnieniu roboczym 1,5 bar (0,15 MPa) przy prędkości $5 \mathrm{~km} / \mathrm{h}$, co pozwoliło uzyskać dawkę cieczy użytkowej wynoszącą 200 1/ha. Podczas aplikacji wykonanych 5.10 .2016 r. i 27.11.2017 r. odnotowano następujące warunki pogodowe, odpowiednio do dat: temperatura $12,5^{\circ} \mathrm{C}$ i $11,4^{\circ} \mathrm{C}$; wilgotność względna powietrza $84,1 \%$ i $75 \%$; prędkość wiatru 1,5-2,6 m/s i 0,8-2,4 m/s; kierunek wiatru zachodni i północny. Średnie temperatury dobowe odnotowane na wysokości 1,5 m w okresie 2 tygodni po opryskiwaniu podano $\mathrm{w}$ tabeli 1 . Sumę opadów deszczu w kolejnych tygodniach przed i po zabiegu oraz w poszczególnych miesiącach badań podano w tabelach 2. i 3 .

Obserwacje zwalczania chwastów przeprowadzono dwukrotnie: wiosną, po ruszeniu wegetacji (BBCH 31-32) oraz około pięć tygodni przed zbiorem pszenicy ozimej (BBCH 85-90). Skład gatunkowy i liczebność chwastów określono w 4 losowo wybranych miejscach na poszczególnych poletkach kontrolnych, każde o powierzchni $0,25 \mathrm{~m}^{2}$. Na poletkach z testowanymi preparatami, skuteczność działania herbicydów oceniono wizualnie, uwzględniając liczebność i kondycję chwastów w porównaniu do ich stanu na poletkach kontrolnych. Fitotoksyczność preparatów względem rośliny uprawnej oceniano kilkakrotnie według metodyki [EPPO PP 1/135 (3)] posługując się skalą procentową (0-100), gdzie 0 - oznacza brak oznak fitotoksycznego oddziaływania, a 100 - całkowite zniszczenie roślin. Wysokość plonu z 1 ha określono dla standardowej wilgotności ziarna na poziomie 14\%. Po zbiorach ustalono masę tysiąca ziaren oraz gęstość ziarna w stanie zsypnym według metod podanych w Polskich Normach (PN-68/R-74017; PN-ISO 7971-2). Zawartość białka, skrobi i glutenu określono na Analizatorze Jakości Ziarna Infratec 1241. Wyniki poddano analizie statystycznej z wykorzystaniem analizy wariancji i testu Tukeya na poziomie istotności $\alpha=0,05$.

\section{Wyniki i dyskusja / Results and discussion}

W doświadczeniach najliczniej reprezentowanymi gatunkami chwastów były: fiołek polny (Viola arvensis Murr.), maruna bezwonna (Matricaria inodora L.), rdestówka powojowata [Fallopia convolvulus (L) Á. Löve], ostróżeczka polna (Consolida regalis L.), mak polny (Papaver rhoeas L.) oraz miotła zbożowa [Apera spicaventi (L.) P. Beauv.]. Skuteczność zniszczenia chwastów przez herbicydy była zgodna z zakresem wskazanym na etykietach, przy czym Komplet 560 SC zwalczył ponadto w stopniu wysokim przetacznik bluszczykowaty (tab. 4-7). Mieszanina diflufenikanu i flufenacetu dała nieco lepsze 
Tabela 1. Średnie temperatury dobowe w okresie 14 dni po zabiegu

Table 1. Daily average temperature during the period of 14 days after the treatment

\begin{tabular}{|c|c|c|c|c|c|c|c|c|c|c|c|c|c|c|}
\hline \multirow{3}{*}{$\begin{array}{l}\text { Rok } \\
\text { Year }\end{array}$} & \multicolumn{14}{|c|}{ Dzień po zabiegu - Day after treatment } \\
\hline & 1 & 2 & 3 & 4 & 5 & 6 & 7 & 8 & 9 & 10 & 11 & 12 & 13 & 14 \\
\hline & \multicolumn{14}{|c|}{$\left[{ }^{\circ} \mathrm{C}\right]$} \\
\hline 2015 & 11,5 & 10,3 & 7,1 & 6,4 & 4,0 & 2,3 & 1,3 & 3,7 & 6,4 & 7,1 & 9,9 & 10,5 & 8,5 & 8,5 \\
\hline 2016 & 0,0 & 0,0 & 3,3 & $-0,2$ & $-0,5$ & 2,5 & 0,2 & $-0,6$ & $-0,3$ & 4,5 & 3,5 & 0,7 & $-1,0$ & $-1,1$ \\
\hline
\end{tabular}

Tabela 2. Suma opadów deszczu w okresie od 2 tygodni przed do 4 tygodni po zabiegu

Table 2. Sum of precipitation in the period from 2 weeks before treatment until 4 weeks after

\begin{tabular}{l|c|c}
\hline \multirow{2}{*}{\multicolumn{1}{c|}{ Okres - Period }} & 2015 & 2016 \\
\cline { 2 - 3 } & \multicolumn{2}{|c}{ suma opadów - sum of precipitation } \\
[mm]
\end{tabular}

Tabela 3. Suma opadów deszczu w okresie badań polowych

Table 3. Sum of precipitation in the period of field experiments

\begin{tabular}{|c|c|c|c|c|c|c|c|c|c|c|c|c|}
\hline \multirow{3}{*}{$\begin{array}{l}\text { Miesiąc } \\
\text { Month }\end{array}$} & & 2015 & & \multirow{3}{*}{$\begin{array}{l}\text { Suma } \\
\text { Sum }\end{array}$} & \multirow{2}{*}{\multicolumn{3}{|c|}{$\begin{array}{c}2016 \\
\text { dekady }-10 \text { days period }\end{array}$}} & \multirow{3}{*}{$\begin{array}{l}\text { Suma } \\
\text { Sum }\end{array}$} & \multirow{2}{*}{\multicolumn{3}{|c|}{$\begin{array}{c}2017 \\
\text { dekady }-10 \text { days period }\end{array}$}} & \multirow{3}{*}{$\begin{array}{l}\text { Suma } \\
\text { Sum }\end{array}$} \\
\hline & \multicolumn{3}{|c|}{ dekady - 10 days period } & & & & & & & & & \\
\hline & I & II & III & & I & II & III & & I & II & III & \\
\hline I & - & - & - & - & 2,9 & 16,7 & 6,3 & 25,9 & 4,0 & 6,0 & 0,4 & 10,4 \\
\hline II & - & - & - & - & 9,7 & 10,0 & 16,6 & 36,3 & 0,0 & 6,3 & 16,4 & 22,7 \\
\hline III & - & - & - & - & 15,5 & 4,8 & 4,7 & 25,0 & 12,3 & 15,4 & 10,4 & 27,7 \\
\hline IV & - & - & - & - & 0,1 & 0,1 & 0,0 & 0,2 & 4,5 & 24,6 & 9,1 & 38,2 \\
\hline $\mathrm{V}$ & - & - & - & - & 0,0 & 18,3 & 9,0 & 27,3 & 50,9 & 0,0 & 13,4 & 64,3 \\
\hline VI & - & - & - & - & 6,0 & 26,5 & 0,0 & 32,5 & 22,6 & 6,7 & 21,8 & 51,1 \\
\hline VII & - & - & - & - & 4,3 & 89,9 & 21,8 & 115,9 & 0,4 & 8,0 & 68,7 & 77,1 \\
\hline VIII & - & - & - & - & 5,8 & 0,1 & 12,6 & 18,5 & - & - & - & - \\
\hline IX & 12,5 & 5,5 & 0,0 & 18,0 & 11,3 & 0,0 & 3,9 & 15,2 & - & - & - & - \\
\hline $\mathrm{X}$ & 0,1 & 24,8 & 5,5 & 30,4 & 0,0 & 21,2 & 15,2 & 36,4 & - & - & - & - \\
\hline $\mathrm{XI}$ & 8,2 & 33,8 & 7,5 & 49,5 & 10,5 & 7,7 & 2,3 & 20,5 & - & - & - & - \\
\hline XII & 6,6 & 17,3 & 2,4 & 26,3 & 14,8 & 17,7 & 7,2 & 39,7 & - & - & - & - \\
\hline
\end{tabular}

Tabela 4. Wpływ herbicydów Komplet 560 EC i Expert Met 56 WG stosowanych z adiuwantami Grounded i OSOL na skuteczność zwalczania chwastów w pszenicy ozimej w sezonie 2015/2016 - ocena wiosną, po ruszeniu wegetacji BBCH 31-32

Table 4. Efficacy of herbicides Komplet 560 EC and Expert Met 56 WG used with adjuvants Grounded and OSOL in winter wheat in the season 2015/2016 - evaluation in spring at the BBCH 31-32 growth stage

\begin{tabular}{|c|c|c|c|c|c|c|c|c|c|}
\hline \multirow{2}{*}{$\begin{array}{l}\text { Kombinacja } \\
\text { Treatment }\end{array}$} & \multirow{2}{*}{$\begin{array}{c}\text { Dawka } \\
\text { Dose } \\
{[\mathrm{kg}, \mathrm{l} / \mathrm{ha}]}\end{array}$} & \multicolumn{7}{|c|}{$\begin{array}{c}\text { Zniszczenie chwastów - Weed control } \\
{[\%]}\end{array}$} & \multirow{2}{*}{$\begin{array}{c}\text { Fitotoksycznośćc } \\
\text { Phytotoxicity } \\
{[\%]}\end{array}$} \\
\hline & & VIOAR & MATIN & POLCO & VERHE & PAPRH & GALAP & CONRE & \\
\hline 1 & 2 & 3 & 4 & 5 & 6 & 7 & 8 & 9 & 10 \\
\hline $\begin{array}{l}\text { Kontrola - Untreated } \\
{\left[\text { szt. } / \mathrm{m}^{2}-\text { No./sqm] }\right.}\end{array}$ & - & (23) & (11) & (2) & $(7,5)$ & $(2,5)$ & $(2,5)$ & (2) & 0 \\
\hline Komplet 560 SC & 0,51 & 100 & 100 & 90 & 100 & 93 & 100 & 77 & 0 \\
\hline Komplet 560 SC + Grounded & $0,5 l+0,4 l$ & 100 & 100 & 92 & 100 & 90 & 100 & 97 & 0 \\
\hline
\end{tabular}




\begin{tabular}{l|c|c|c|c|c|c|c|c|c}
\hline \multicolumn{1}{c|}{1} & 2 & 3 & 4 & 5 & 6 & 7 & 8 & 9 & 10 \\
\hline Komplet 560 SC + OSOL & $0,5 \mathrm{l}+0,25 \mathrm{l}$ & 99 & 100 & 93 & 100 & 90 & 100 & 98 & 0 \\
\hline $\begin{array}{l}\text { Expert Met 56 WG } \\
\begin{array}{l}\text { Expert Met 56 WG } \\
+ \text { Grounded }\end{array}\end{array}$ & $0,35 \mathrm{~kg}$ & 53 & 95 & 95 & 97 & 73 & 80 & 87 & 0 \\
\hline Expert Met 56 WG + OSOL & $0,35 \mathrm{~kg}+0,25 \mathrm{l}$ & 37 & 95 & 65 & 100 & 100 & 88 & 63 & 0 \\
\hline
\end{tabular}

VIOAR - Viola arvensis, MATIN - Matricaria maritima ssp. inodora, POLCO - Fallopia convolvulus, VERHE - Veronica hederifolia,

PAPRH - Papaver rhoeas, GALAP - Galium aparine, CONRE - Consolida regalis

Tabela 5. Wpływ herbicydów Komplet 560 EC i Expert Met 56 WG stosowanych z adiuwantami Grounded i OSOL na skuteczność zwalczania chwastów w pszenicy ozimej w sezonie 2015/2016 - ocena pięć tygodni przed zbiorem pszenicy ozimej (BBCH 85-90)

Table 5. Efficacy of herbicides Komplet 560 EC and Expert Met 56 WG used with adjuvants Grounded and OSOL in winter wheat in the season 2015/2016 - evaluation about 5 weeks before harvest (BBCH 85-90)

\begin{tabular}{|c|c|c|c|c|c|c|c|c|}
\hline \multirow{2}{*}{$\begin{array}{l}\text { Kombinacja } \\
\text { Treatment }\end{array}$} & \multirow{2}{*}{$\begin{array}{l}\text { Dawka } \\
\text { Dose } \\
{[\mathrm{kg}, \mathrm{l} / \mathrm{ha}]}\end{array}$} & \multicolumn{6}{|c|}{$\begin{array}{c}\text { Zniszczenie chwastów - Weed control } \\
{[\%]}\end{array}$} & \multirow{2}{*}{$\begin{array}{c}\text { Fitotoksyczność } \\
\text { Phytotoxicity } \\
{[\%]}\end{array}$} \\
\hline & & VIOAR & MATIN & POLCO & PAPRH & CONRE & APESV & \\
\hline $\begin{array}{l}\text { Kontrola - Untreated } \\
{[\text { szt./m² - No./sqm] }}\end{array}$ & - & $(21,5)$ & $(5,5)$ & $(2,0)$ & $(2,0)$ & $(2,0)$ & (25) & 0 \\
\hline Komplet 560 SC & 0,51 & 99 & 93 & 70 & 95 & 99 & 100 & 0 \\
\hline Komplet 560 SC + Grounded & $0,5 l+0,4 l$ & 99 & 99 & 90 & 80 & 98 & 100 & 0 \\
\hline Komplet 560 SC + OSOL & $0,5 l+0,25 l$ & 100 & 100 & 90 & 95 & 100 & 100 & 0 \\
\hline Expert Met 56 WG & $0,35 \mathrm{~kg}$ & 62 & 83 & 50 & 95 & 73 & 99 & 0 \\
\hline $\begin{array}{l}\text { Expert Met } 56 \text { WG } \\
+ \text { Grounded }\end{array}$ & $0,35 \mathrm{~kg}+0,4 \mathrm{l}$ & 47 & 89 & 40 & 100 & 88 & 100 & 0 \\
\hline Expert Met 56 WG + OSOL & $0,35 \mathrm{~kg}+0,25 \mathrm{l}$ & 47 & 83 & 50 & 80 & 85 & 100 & 0 \\
\hline
\end{tabular}

VIOAR - Viola arvensis, MATIN - Matricaria maritima ssp. inodora, POLCO - Fallopia convolvulus, PAPRH - Papaver rhoeas,

CONRE - Consolida regalis, APESV - Apera spica-venti

Tabela 6. Wpływ herbicydów Komplet 560 EC i Expert Met 56 WG stosowanych z adiuwantami Grounded i OSOL na skuteczność zwalczania chwastów w pszenicy ozimej w sezonie 2016/2017 - ocena wiosną, po ruszeniu wegetacji BBCH 31-32

Table 6. Efficacy of herbicides Komplet 560 EC and Expert Met 56 WG used with adjuvants Grounded and OSOL in winter wheat in the season 2015/2016 - evaluation in spring at the BBCH 31-32 growth stage

\begin{tabular}{|c|c|c|c|c|c|c|c|c|c|}
\hline \multirow{2}{*}{$\begin{array}{l}\text { Kombinacja } \\
\text { Treatment }\end{array}$} & \multirow{2}{*}{$\begin{array}{l}\text { Dawka } \\
\text { Dose } \\
{[\mathrm{kg}, \mathrm{l} / \mathrm{ha}]}\end{array}$} & \multicolumn{7}{|c|}{$\begin{array}{c}\text { Zniszczenie chwastów - Weed control } \\
{[\%]}\end{array}$} & \multirow{2}{*}{$\begin{array}{c}\text { Fitotoksyczność } \\
\text { Phytotoxicity } \\
{[\%]}\end{array}$} \\
\hline & & VIOAR & MATIN & POLCO & VERHE & PAPRH & GALAP & CONRE & \\
\hline $\begin{array}{l}\text { Kontrola - Untreated } \\
{\left[\mathrm{szt} . / \mathrm{m}^{2}-\text { No./sqm] }\right.}\end{array}$ & - & $(5,3)$ & $(8,0)$ & $(10,0)$ & $(3,0)$ & $(7,0)$ & $(4,0)$ & $(3,8)$ & 0 \\
\hline Komplet 560 SC & 0,51 & 98 & 99 & 77 & 100 & 100 & 100 & 98 & 0 \\
\hline Komplet 560 SC + Grounded & $0,5 l+0,4 l$ & 100 & 98 & 79 & 98 & 99 & 100 & 99 & 0 \\
\hline Komplet 560 SC + OSOL & $0,5 l+0,25 l$ & 100 & 100 & 95 & 100 & 100 & 100 & 97 & 0 \\
\hline Expert Met 56 WG & $0,35 \mathrm{~kg}$ & 87 & 88 & 23 & 90 & 95 & 92 & 90 & 0 \\
\hline $\begin{array}{l}\text { Expert Met } 56 \text { WG } \\
\text { + Grounded }\end{array}$ & $0,35 \mathrm{~kg}+0,4 \mathrm{l}$ & 88 & 90 & 40 & 92 & 96 & 92 & 91 & 0 \\
\hline Expert Met 56 WG + OSOL & $0,35 \mathrm{~kg}+0,25 \mathrm{l}$ & 94 & 92 & 57 & 97 & 99 & 93 & 95 & 0 \\
\hline
\end{tabular}

VIOAR - Viola arvensis, MATIN - Matricaria maritima ssp. inodora, POLCO - Fallopia convolvulus, VERHE - Veronica hederifolia,

PAPRH - Papaver rhoeas, GALAP - Galium aparine, CONRE - Consolida regalis

rezultaty niż metrybuzyna $\mathrm{z}$ flufenacetem, choć nie udowodniono tego narzędziami analizy statystycznej. Spośród gatunków przedstawionych w tabelach 4-7 środek Ekspert Met 56 WG ze średnią skutecznością zwalczał jedynie fiołka polnego w sezonie 2015/2016 i rdestówkę powojo- watą w obu sezonach, o tym chwaście nie informuje etykieta preparatu. Preparat Komplet 560 SC zwalczał w stopniu średnim tylko rdestówkę powojowatą, co stwierdzono tylko w ocenie 5 tygodni przed zbiorem. 
Tabela 7. Wpływ herbicydów Komplet 560 EC i Expert Met 56 WG stosowanych z adiuwantami Grounded i OSOL na skuteczność zwalczania chwastów w pszenicy ozimej w sezonie 2016/2017 - ocena pięć tygodni przed zbiorem pszenicy ozimej (BBCH 85-90)

Table 7. Efficacy of herbicides Komplet 560 EC and Expert Met 56 WG used with adjuvants Grounded and OSOL in winter wheat in the season 2015/2016 - evaluation about 5 weeks before harvest (BBCH 85-90)

\begin{tabular}{|c|c|c|c|c|c|c|c|c|c|}
\hline \multirow{2}{*}{$\begin{array}{l}\text { Kombinacja } \\
\text { Treatment }\end{array}$} & \multirow{2}{*}{$\begin{array}{l}\text { Dawka } \\
\text { Dose } \\
{[\mathrm{kg}, \mathrm{l} / \mathrm{ha}]}\end{array}$} & \multicolumn{7}{|c|}{$\begin{array}{c}\text { Zniszczenie chwastów - Weed control } \\
{[\%]}\end{array}$} & \multirow{2}{*}{$\begin{array}{c}\text { Fitotoksyczność } \\
\text { Phytotoxicity }\end{array}$} \\
\hline & & VIOAR & MATIN & POLCO & PAPRH & GALAP & CONRE & APESV & \\
\hline $\begin{array}{l}\text { Kontrola - Untreated } \\
{\left[\mathrm{szt} . / \mathrm{m}^{2}-\text { No./sqm] }\right.}\end{array}$ & - & $(8,3)$ & $(6,3)$ & $(5,5)$ & $(3,3)$ & $(3,3)$ & $(3,3)$ & $(10,3)$ & 0 \\
\hline Komplet 560 SC & 0,51 & 100 & 100 & 67 & 100 & 100 & 100 & 100 & 0 \\
\hline Komplet 560 SC + Grounded & $0,5 l+0,4 l$ & 100 & 100 & 83 & 100 & 97 & 83 & 100 & 0 \\
\hline Komplet 560 SC + OSOL & $0,51+0,251$ & 100 & 100 & 87 & 100 & 100 & 93 & 100 & 0 \\
\hline Expert Met 56 WG & $0,35 \mathrm{~kg}$ & 93 & 68 & 37 & 100 & 93 & 100 & 100 & 0 \\
\hline $\begin{array}{l}\text { Expert Met } 56 \text { WG } \\
\text { + Grounded }\end{array}$ & $0,35 \mathrm{~kg}+0,4 \mathrm{l}$ & 100 & 68 & 37 & 100 & 93 & 97 & 100 & 0 \\
\hline Expert Met 56 WG + OSOL & $0,35 \mathrm{~kg}+0,25 \mathrm{l}$ & 98 & 75 & 50 & 98 & 100 & 100 & 93 & 0 \\
\hline
\end{tabular}

VIOAR - Viola arvensis, MATIN - Matricaria maritima ssp. inodora, POLCO - Fallopia convolvulus, PAPRH - Papaver rhoeas,

GALAP - Galium aparine, CONRE - Consolida regalis, APESV - Apera spica-venti

Tabela 8. Średnie wartości plonu i jego parametrów dla pszenicy ozimej w 2016 roku

Table 8. Mean yield values and its parameters for winter wheat in 2016

\begin{tabular}{l|c|c|c|c|c|c|c}
\hline \multicolumn{1}{c|}{$\begin{array}{c}\text { Kombinacja } \\
\text { Treatment }\end{array}$} & $\begin{array}{c}\text { Dawka } \\
\text { Dose } \\
\text { [g, l/ha] }\end{array}$ & $\begin{array}{c}\text { Masa } \\
\text { 1000 ziaren } \\
\text { Weight of } \\
1000 \text { grains } \\
\text { [g] }\end{array}$ & $\begin{array}{c}\text { Gęstość } \\
\text { Density } \\
{[\mathrm{kg} / \mathrm{hl}]}\end{array}$ & $\begin{array}{c}\text { Białko } \\
\text { Protein } \\
\text { content } \\
{[\%]}\end{array}$ & $\begin{array}{c}\text { Skrobia } \\
\text { Starch } \\
\text { content } \\
{[\%]}\end{array}$ & $\begin{array}{c}\text { Gluten } \\
\text { Gluten } \\
\text { content } \\
{[\%]}\end{array}$ & $\begin{array}{c}\text { Plon } \\
\text { Yield } \\
{[\mathrm{t} / \mathrm{ha}]}\end{array}$ \\
\hline Kontrola - Untreated & - & $42,12 \mathrm{a}$ & $75,32 \mathrm{a}$ & $11,35 \mathrm{a}$ & $69,40 \mathrm{a}$ & $24,75 \mathrm{a}$ & $3,82 \mathrm{bc}$ \\
\hline Komplet 560 SC & $0,5 \mathrm{l}$ & $43,68 \mathrm{a}$ & $74,65 \mathrm{a}$ & $11,50 \mathrm{a}$ & $69,30 \mathrm{a}$ & $25,27 \mathrm{a}$ & $5,70 \mathrm{a}$ \\
\hline Komplet 560 SC + Grounded & $0,5 \mathrm{l}+0,4 \mathrm{l}$ & $41,02 \mathrm{a}$ & $74,28 \mathrm{a}$ & $11,40 \mathrm{a}$ & $69,10 \mathrm{a}$ & $24,70 \mathrm{a}$ & $5,61 \mathrm{ab}$ \\
\hline Komplet 560 SC + OSOL & $0,5 \mathrm{l}+0,25 \mathrm{l}$ & $42,22 \mathrm{a}$ & $74,15 \mathrm{a}$ & $11,13 \mathrm{a}$ & $69,30 \mathrm{a}$ & $24,03 \mathrm{a}$ & $5,69 \mathrm{a}$ \\
\hline Expert Met 56 WG & $0,35 \mathrm{~kg}$ & $42,39 \mathrm{a}$ & $73,98 \mathrm{a}$ & $11,00 \mathrm{a}$ & $68,77 \mathrm{a}$ & $23,63 \mathrm{a}$ & $4,77 \mathrm{~b}$ \\
\hline $\begin{array}{l}\text { Expert Met 56 WG } \\
+ \text { Grounded }\end{array}$ & $0,35 \mathrm{~kg}+0,4 \mathrm{l}$ & $39,83 \mathrm{a}$ & $73,94 \mathrm{a}$ & $10,97 \mathrm{a}$ & $69,23 \mathrm{a}$ & $23,63 \mathrm{a}$ & $3,60 \mathrm{c}$ \\
\hline Expert Met 56 WG + OSOL & $0,35 \mathrm{~kg}+0,25 \mathrm{l}$ & $42,59 \mathrm{a}$ & $73,38 \mathrm{a}$ & $11,23 \mathrm{a}$ & $69,07 \mathrm{a}$ & $24,23 \mathrm{a}$ & $4,05 \mathrm{bc}$ \\
\hline
\end{tabular}

Średnie oznaczone tymi samymi literami nie różnią się istotnie przy $\alpha=0,05$ - Mean values marked with the same letter do not differ significantly at $\alpha=0.05$

Tabela 9. Średnie wartości plonu i jego parametrów dla pszenicy ozimej w 2017 roku

Table 9. Mean yield values and its parameters for winter wheat in 2017

\begin{tabular}{|c|c|c|c|c|c|c|c|}
\hline $\begin{array}{c}\text { Kombinacja } \\
\text { Treatment }\end{array}$ & $\begin{array}{c}\text { Dawka } \\
\text { Dose } \\
{[\mathrm{g}, \mathrm{l} / \mathrm{ha}]}\end{array}$ & $\begin{array}{c}\text { Masa } \\
1000 \text { ziaren } \\
\text { Weight of } \\
1000 \text { grains } \\
\text { [g] }\end{array}$ & $\begin{array}{c}\text { Gęstość } \\
\text { Density } \\
{[\mathrm{kg} / \mathrm{hl}]}\end{array}$ & $\begin{array}{c}\text { Białko } \\
\text { Protein } \\
\text { content } \\
{[\%]}\end{array}$ & $\begin{array}{c}\text { Skrobia } \\
\text { Starch } \\
\text { content } \\
{[\%]}\end{array}$ & $\begin{array}{c}\text { Gluten } \\
\text { Gluten } \\
\text { content } \\
{[\%]}\end{array}$ & $\begin{array}{l}\text { Plon } \\
\text { Yield } \\
\text { [t/ha] }\end{array}$ \\
\hline Kontrola - Untreated & - & 51,36 a & 78,87 a & 11,53 a & 71,80 a & 26,43 a & $7,76 \mathrm{a}$ \\
\hline Komplet 560 SC & 0,51 & 51,13 a & 78,73 a & 11,40 a & 71,95 a & 26,10 a & $7,83 \mathrm{a}$ \\
\hline Komplet 560 SC + Grounded & $0,5 l+0,4 l$ & 50,77 a & 78,72 a & 11,58 a & $71,80 \mathrm{a}$ & $26,60 \mathrm{a}$ & $7,77 \mathrm{a}$ \\
\hline Komplet 560 SC + OSOL & $0,5 \mathrm{l}+0,25 \mathrm{l}$ & 50,75 a & 78,68 a & 11,65 a & $71,60 \mathrm{a}$ & 27,05 a & $8,22 \mathrm{a}$ \\
\hline Expert Met 56 WG & $0,35 \mathrm{~kg}$ & 50,49 a & 78,64 a & 11,65 a & $71,05 \mathrm{a}$ & $27,00 \mathrm{a}$ & 7,79 a \\
\hline $\begin{array}{l}\text { Expert Met } 56 \text { WG } \\
+ \text { Grounded }\end{array}$ & $0,35 \mathrm{~kg}+0,4 \mathrm{l}$ & 50,34 a & 78,51 a & 11,58 a & 71,63 a & 26,53 a & $7,66 \mathrm{a}$ \\
\hline Expert Met 56 WG + OSOL & $0,35 \mathrm{~kg}+0,25 \mathrm{l}$ & 50,10 a & $78,50 \mathrm{a}$ & $12,05 \mathrm{a}$ & 71,33 a & 27,62 a & 7,89 a \\
\hline
\end{tabular}

Średnie oznaczone tymi samymi literami nie różnią się istotnie przy $\alpha=0,05$ - Mean values marked with the same letter do not differ significantly at $\alpha=0.05$ 
Z uwagi na warunki wilgotnościowe w glebie pobieranie herbicydów przez kiełkujące i wschodzące chwasty mogło być początkowo nieco słabsze jesienią roku 2015 niż 2016 (tab. 2). Po wykonaniu zabiegu w 2015 r. panowały jednak korzystniejsze warunki termiczne w glebie (tab. 1). Splot tych czynników z przebiegiem opadów deszczu wiosną (tab. 3) mógł mieć związek $\mathrm{z}$ nieco słabszym oddziaływaniem herbicydu Ekspert Met 56 WG na fiołka polnego w sezonie 2015/2016, w przeciwieństwie do rdestówki powojowatej, która była gorzej zwalczana w sezonie $2016 / 2017$. Pozostałe chwasty były jednak zwalczane $\mathrm{w}$ równie wysokim stopniu $\mathrm{w}$ obu sezonach wegetacyjnych.

Adiuwanty, Grounded i OSOL, nie wpłynęły w znacznym stopniu na skuteczność chwastobójczą zastosowanych herbicydów. Tylko w przypadku rdestówki powojowatej dodatek obu adiuwantów zwiększał nieznacznie skuteczność działania herbicydu Komplet 560 SC. Trzeba jednak zaznaczyć, że oba herbicydy zastosowano w maksymalnych dawkach zalecanych do jednorazowego zabiegu, które okazały się wysoce skuteczne. Należy rozważyć możliwość obniżenia dawki tych herbicydów podczas łącznego stosowania z adiuwantami. Kucharski i wsp. (2012) wykazali, że w przypadku pobieranego $\mathrm{z}$ gleby diflufenikanu dodatek adiuwanta olejowego, organosilikonowego lub wielokomponentowego umożliwił uzyskanie wysokiej skuteczności chwastobójczej w pszenicy ozimej przy dawce obniżonej o 40\%. Kucharski i Domaradzki (2008) twierdzą, że łączne zastosowanie herbicydów z adiuwantami o działaniu doglebowym ma korzystny wpływ na wydłużenie czasu skutecznego działania na kiełkujące chwasty. Wyniki badań własnych nie dały jednak podstawy do potwierdzenia takiego efektu, z uwagi na wysoki poziom zabezpieczenia plantacji przed zachwaszczeniem w wyniku skutecznego działania herbicydów w pełnych dawkach.

Badane $\mathrm{w}$ doświadczeniach mieszaniny herbicydów $\mathrm{z}$ adiuwantami nie miały fitotoksycznego wpływu na rośliny pszenicy ozimej (tab. 4-7). Nie wykazano również istotnych różnic w podstawowych parametrach jakościowych ziarna: masie tysiąca ziaren i gęstości zsypnej. Jakość ziarna charakteryzowana przez zawartość białka, skrobi i glutenu również nie różniła się znacząco w poszczególnych latach (tab. 8, 9).

Plon pszenicy ozimej, jak i masa tysiąca ziaren były większe w roku 2017 niż 2016 (tab. 8, 9). Miało to związek z korzystniejszym dla wzrostu pszenicy ozimej przebiegiem pogody wiosną, zwłaszcza z większymi opadami od kwietnia do czerwca. Natomiast na przedwiośniu i wiosną 2016 r. rozkład opadów doprowadził do większej konkurencji ze strony chwastów i zróżnicowania wpływu zabiegów odchwaszczania na plonowanie pszenicy ozimej (tab. 3,8 ). W rezultacie uzyskano niższe plony w obiektach traktowanych preparatem Ekspert Met 56 WG niż Komplet 560 EC. Ponadto adiuwant Grounded w mieszaninie z herbicydem Ekspert Met 56 WG przyczynił się do istotnego zmniejszenia plonu $\mathrm{w}$ porównaniu do zastosowania samego herbicydu. W przypadku mieszaniny adiuwanta z preparatem Komplet 560 SC i mieszaniny adiuwanta OSOL z obydwoma herbicydami nie stwierdzono negatywnego wpływu na plonowanie pszenicy ozimej. Z kolei, w wyniku korzystnego przebiegu warunków pogodowych w okresie wiosennym 2017 r. i po skutecznej ochronie przed zachwaszczeniem (zabiegi samymi herbicydami i z dodatkiem adiuwantów doglebowych) uzyskano wyrównane i stabilne plonowanie pszenicy ozimej.

\section{Wnioski / Conclusions}

1. Wyniki badań wskazują na możliwość stosowania herbicydów Komplet 560 EC oraz Expert Met 56 WG z dodatkiem adiuwantów doglebowych Grounded i OSOL w uprawie pszenicy ozimej.

2. Aplikacja herbicydów działających głównie przez system korzeniowy z dodatkiem adiuwantów o działaniu doglebowym może wpływać korzystnie na wydłużenie ich aktywności chwastobójczej. Nie zostało to jednak potwierdzone $w$ badaniach własnych z użyciem maksymalnych dawek wysoce aktywnych herbicydów w trakcie jesiennych zabiegów w pszenicy ozimej (BBCH 11-12).

3. Plonowanie pszenicy ozimej było uzależnione od przebiegu warunków pogodowych, wielkości zachwaszczenia i skuteczności działania herbicydów $\mathrm{z}$ dodatkiem i bez dodatku adiuwantów.

4. Badane herbicydy stosowane pojedynczo, jak i w połączeniu $\mathrm{z}$ adiuwantami doglebowymi były w pełni selektywne dla roślin pszenicy ozimej odmiany Arkadia.

\section{Literatura / References}

Adamczewski K., Matysiak R. 2005. Znaczenie i korzyści wynikające ze stosowania adiuwantów z herbicydami sulfonylomocznikowymi. [The effects and benefits of adjuvants used with sulfonylourea herbicides]. Progress in Plant Protection/Postępy w Ochronie Roślin 45 (1): 17-24.

Bayer D.E., Foy C.L. 1982. Action and fate of adjuvants in soils. Weed Science 34: 84-92.

EPPO PP 1/135 (3). Ocena skuteczności działania środków ochrony roślin. [Evaluation biologique des produits phytosanitaires]. Bulletin OEPP/EPPO Bulletin 37: 4-10.

Foster D.K., Taylor W.A., Parsons R.G. 2006. Effects of adjuvants on the deposition, retention and efficacy of pesticides. Aspects of Applied Biology 77 (1): 127-132.

Foy C.L. 1992. Influence of certain surfactants on the mobility of selected herbicides in soil. p. 349-365. In: "Adjuvants for Agrichemicals” (C.L. Foy, ed.). CRC Press, Boca Raton, USA.

Jain R., Singh M. 1992. Effect of a synthetic polymer on adsorption and leaching of herbicides in soil. p. 329-348. In: "Adjuvants for Agrichemicals” (C.L. Foy, ed.). CRC Press, Boca Raton, USA.

Krogh K.A., Halling-Sørensen B., Mogensen B.B., Vejrup K.V. 2003. Environmental properties and effects of nonionic surfactant adjuvants in pesticides: a review. Chemosphere 50 (7): 871-901. DOI: https://doi.org/10.1016/S0045-6535(02)00648-3. 
Kucharski M. 2004. Degradation of phenmedipham in soil under laboratory conditions. Vegetable Crops Research Bulletin 60 (2): $63-70$.

Kucharski M., Domaradzki K. 2008. Stosowanie adiuwantów z metamitronem w zabiegach przedwschodowych - wpływ na skuteczność chwastobójczą oraz pozostałości herbicydu w glebie. [Adjuvants with metamitron in preemergence treatment - influence on weed control efficacy and herbicide residues in soil]. Progress in Plant Protection/Postępy w Ochronie Roślin 48 (1): 281-286.

Kucharski M., Sadowski J. 2006. Effect of adjuvants on herbicide residues level in soil and plant. Journal of Plant Diseases and Protection 20: 971-975.

Kucharski M., Sadowski J. 2009. Influence of adjuvants on behavior of phenmedipham in plant and soil. Polish Journal of Agronomy 1: $32-36$.

Kucharski M., Sadowski J., Kieloch R. 2012. Adiuwanty w zabiegach przedwschodowych - wpływ na skuteczność diflufenikanu i jakość ziarna pszenicy ozimej. [Adjuvants in preemergence application - influence on diflufenican efficacy and quality of winter wheat grain]. Progress in Plant Protection/Postępy w Ochronie Roślin 52 (1): 51-54. DOI: http://dx.doi.org/10.14199/ppp-2012-010.

Kucharski M., Sadowski J., Wujek B., Trajdos J. 2011. Influence of adjuvants addition on lenacil residues in plant and soil. Polish Journal of Agronomy 5: 39-42.

McMullan P.M., Thomas J.M., Volgas G. 1998. HM9679 - A spray adjuvant for soil-applied herbicides. p. 285-290. In: Proceedings 5th International Symposium on Adjuvants for Agrochemicals. Memphis, Tennessee, USA, 17-21 August 1998, 519 pp.

PN-68/R-74017:1968. Ziarno zbóż i nasiona strączkowe jadalne - Oznaczanie masy 1000 ziarn.

PN-ISO 7971-2:1998. Ziarno zbóż - Oznaczanie gęstości w stanie zsypnym, zwanej „masą hektolitra” - Metoda rutynowa.

Swarcewicz M.K., Mulinski Z., Zbiec I. 1998. Influence of spray adjuvants on the behavior of trifluralin in the soil. Bulletin of Environmental Contamination and Toxicology 60: 569-576.

Zontek S.J., Kostka S.J. 2012. Understanding the different wetting agent chemistries. Green Section Record 50 (15): 1-6. http://gsrpdf.lib.msu.edu/ticpdf.py?file=/article/zontek-understanding-7-20-12.pdf [Accessed: 20.06.2012]. 